\title{
De zorg voor ouderen thuis
}

Citation for published version (APA):

Zwakhalen, S. (2018). De zorg voor ouderen thuis: veel spreiding, niet gemiddeld. Maastricht University. https://doi.org/10.26481/spe.20181214sz

Document status and date:

Published: 14/12/2018

DOI:

10.26481/spe.20181214sz

Document Version:

Publisher's PDF, also known as Version of record

\section{Please check the document version of this publication:}

- A submitted manuscript is the version of the article upon submission and before peer-review. There can be important differences between the submitted version and the official published version of record.

People interested in the research are advised to contact the author for the final version of the publication, or visit the DOI to the publisher's website.

- The final author version and the galley proof are versions of the publication after peer review.

- The final published version features the final layout of the paper including the volume, issue and page numbers.

Link to publication

\footnotetext{
General rights rights.

- You may freely distribute the URL identifying the publication in the public portal. please follow below link for the End User Agreement:

www.umlib.nl/taverne-license

Take down policy

If you believe that this document breaches copyright please contact us at:

repository@maastrichtuniversity.nl

providing details and we will investigate your claim.
}

Copyright and moral rights for the publications made accessible in the public portal are retained by the authors and/or other copyright owners and it is a condition of accessing publications that users recognise and abide by the legal requirements associated with these

- Users may download and print one copy of any publication from the public portal for the purpose of private study or research.

- You may not further distribute the material or use it for any profit-making activity or commercial gain

If the publication is distributed under the terms of Article $25 \mathrm{fa}$ of the Dutch Copyright Act, indicated by the "Taverne" license above, 
Prof.Dr. Sandra M.G. Zwakhalen

Faculty of Health, Medicine and Life Sciences

\section{De zorg voor ouderen thuis : veel spreiding, niet gemiddeld}


De Zorg voor Ouderen Thuis; Veel Spreiding, Niet Gemiddeld.

Inaugurele rede uitgesproken bij de aanvaarding van de leerstoel Verplegingswetenschap van de Universiteit Maastricht op vrijdag 14 december 2018.

\section{Prof. Dr. S.M.G Zwakhalen}

Geachte (pro)rector, vice-decaan van de faculteit $\mathrm{FHML}$, leden van het college van toezicht, zeer geleerde en gewaarde toehoorders. Dearest colleagues from other countries, I am greatly honored that you are present today.

Het is een koude winterdag in december 1994, als ik in mijn spiksplinternieuwe Daihatsu Cuore (van meer dan tien jaar oud) op pad ga in de wijk. Elektronische dossiers zijn er nog niet, mobiele telefoons evenmin. Op dat moment ben ik 21 jaar en net geslaagd voor de hboopleiding Verpleegkunde in Sittard. Ik ben op weg naar mevrouw De Jong.

Mevrouw De Jong is zeventig jaar, is alleenstaand sinds het overlijden van haar man drie jaar daarvoor en lijdt sinds enkele jaren aan frontaalkwabdementie. Fysiek is mevrouw in goede conditie, maar cognitief is ze dusdanig beperkt dat ze dagelijkse ondersteuning nodig heeft. Ze woont in een oude boerderij, waar driemaal per dag de thuiszorg langskomt om haar te helpen bij activiteiten als wassen en aankleden, het klaarmaken van maaltijden en het innemen van haar medicatie. Ik kom al geruime tijd bij mevrouw De Jong en mijn auto lijkt op die van haar zoon. 's Ochtends doet ze de voordeur open en staat ze in de deuropening. Telkens is de teleurstelling groot als ze ziet dat niet haar zoon, maar ik kom aangereden in mijn grijze koekblik. Sterker nog, ze is niet alleen teleurgesteld: ze is er ook van overtuigd dat ik de auto van haar zoon gestolen heb! En dan ben ik de drempel van de voordeur nog niet eens gepasseerd. De achterdocht had niet groter kunnen zijn en ik vraag me oprecht af hoe ik ervoor kan zorgen dat mevrouw vandaag onder de douche wilt. Dat probleem herkennen mijn collega's in de wijk. Soms lukt het zelfs dagenlang niet om mevrouw zover te krijgen dat ze wil douchen of zelfs maar om haar wat op te frissen.

Vanuit verpleegkundig oogpunt is het probleem helder: mevrouw is dusdanig beperkt dat ze dagelijks hulp nodig heeft bij alledaagse activiteiten zoals wassen en aankleden. Maar wat in de verpleegkundige theorie klopt, is in de verpleegkundige praktijk vaak net iets ingewikkelder. De achterdocht van mevrouw ebt niet weg wanneer ik eenmaal binnen ben. Ze maakt me duidelijk dat haar portemonnee weg is en dat iemand haar geld heeft gestolen. Dan volgt haar pertinente vraag aan mij: "Wat kom jij eigenlijk doen?" Zonder enige aarzeling, en zonder er ook maar iets verkeerds in te zien, zeg ik: "Ik kom u helpen met douchen." En ja, dan is het hek van de dam. 
"Ik heb al gedoucht. Ik heb trouwens geen hulp nodig. Wat denk je eigenlijk wel? Ik woon hier al jaren en het lukt me prima." O nee, ik heb het verknald! Ik ben nu al twintig minuten binnen en heb mevrouw enkel van haar stuk gebracht in plaats van ook maar íéts te doen om haar te ondersteunen in haar behoeften. Ik besluit een stapje terug te doen en even stil te staan bij de foto's in de gang. Voorzichtig vraag ik wie er op die prachtige foto's staan. En ja, het lijkt te werken! Ze vertelt honderduit over de zwart-witte trouwfoto's aan de muur. De verhalen doen ons beiden wegsmelten. Dat het verhaal dat mevrouw vertelt geenszins kan kloppen, aangezien tijd, plaats en personen niet met elkaar overeenkomen, doet er niet toe.

Op een van de foto's is de winkel van een naaiatelier te zien. Mevrouw De Jong vertelt dat haar moeder haar straks komt halen om naar de nieuwe kledingcollectie te kijken. Ik hoor de opwinding in haar stem. Dan besluit ik mijn kans te wagen. Ter plekke verzin ik dat de nieuwe kledingcollectie volgens mij net binnen is. In een vlotte beweging doe ik haar kastdeur open en laat ik haar vol verwondering naar haar eigen "nieuwe" kledingcollectie kijken, die ze door de dementie niet meer herkent. "Zal ik u even helpen om een van deze prachtige kledingstukken aan te trekken?" "Zou u dat willen doen?" vraagt mevrouw De Jong verbaasd. Uiteraard knik ik instemmend en terwijl ze zich uitkleedt, maak ik van de gelegenheid gebruik om haar even op te frissen. Vanaf dat moment besluit ik altijd te kijken naar de foto's in huis.

Vanaf die dag is me ook duidelijk dat de doelen en behoeften van de zorgvrager en de zorgverlener soms ver uit elkaar liggen. De eerlijkheid gebiedt me te zeggen dat ik, als net gediplomeerde verpleegkundige, in de situatie van mevrouw De Jong ook maar wat aanmodderde. Ik volgde mijn intuïtie, iets wat verpleegkundigen net iets te vaak doen. Door de nodige creativiteit pakte het goed uit, maar mijn handelen was natuurlijk op geen enkele wijze wetenschappelijk onderbouwd.

Elke dag zou voor verpleegkundigen de centrale vraag bij hun werk moeten zijn: wat is de beste zorg in een bepaalde situatie? Om die vraag te beantwoorden is wetenschappelijk onderzoek van onmiskenbaar belang. Het ultieme doel daarvan is het verlenen van de juiste zorg op de juiste manier en het juiste moment, afgestemd op de voorkeuren van de cliënt. In de situatie met mevrouw De Jong ervoer ik een gebrek aan kennis over de wenselijke manier van communiceren in geval van dementie. En was douchen nu eigenlijk wel wenselijk in het geval van mevrouw De Jong?

Dat je als verpleegkundige iets kunt bijdragen aan de dagelijkse gang van zaken in de zorg voor ouderen thuis, kan me tot op de dag van vandaag ontroeren. Ik vind het bijzonder om achter zo veel verschillende voordeuren te mogen komen. Achter elke voordeur ging een persoonlijk verhaal schuil. Vandaag wil ik in mijn rede een aantal van die deuren voor u openen om u zo enig inzicht te geven in de diversiteit van de zorg voor ouderen thuis en de uitdagingen die daarmee gepaard gaan. 
In het vervolg van deze rede wil ik ingaan op mijn leeropdracht Verplegingswetenschap, die specifiek gericht is op de zorg voor ouderen thuis. Dat doe ik aan de hand van de volgende vragen:

1. Hoe heeft de zorg thuis, en specifiek voor ouderen thuis, zich ontwikkeld en welke rol speelt de verpleging daarbij?

2. Hoe kan wetenschappelijk onderzoek de zorg verbeteren?

3. Wat ga ik in de toekomst doen om een bijdrage te leveren aan de kennis op het gebied van de zorg voor ouderen thuis?

4. Welke boodschap neemt u mee naar huis?

Ontwikkeling in de zorg voor ouderen thuis en de rol van de verpleging In de negentiende eeuw nam de medische wetenschap een vlucht, die van invloed was op het verpleegkundig handelen (Dane, 1980). Niemand minder dan Florence Nightingale zorgde dat verplegen werd erkend als beroep. De eerste opleidingen tot verpleegkundige (destijds verpleegster genoemd) werden opgericht, evenals het eerste vakblad, het tijdschrift voor Verpleegkundigen (het TVZ) (www.nfi.nl).

Eind negentiende eeuw kwam de zorg thuis tot stand vanuit de zogeheten kruisverenigingen. In Maastricht en omgeving betrof dit veelal het Groene Kruis, de voorloper van een van onze zorgpartners, Envida. De wijkverpleegster vormde een belangrijke schakel tussen huisarts en patiënt in het geheel van de zorg. De zorg aan huis voor zieken was veelal preventief van aard, bijvoorbeeld gericht op voorlichting. Rust, regelmaat en reinheid waren van onmiskenbaar belang (Hulst van, 1916). De wijkverpleegster genoot een bepaald aanzien in de wijk. Ze was autonoom en regelde waar nodig de zorg binnen het gezin.

In de periode van schaarste tijdens en na de oorlog lag de nadruk op hygiëne en het voorkomen van besmettelijke ziektes zoals TBC. De wijkverpleegster gaf adviezen, die vaak indruisten tegen de gewoonten binnen het gezin (Boom van der, Philipsen \& Stevens 2004). U kunt zich voorstellen dat het veelvuldig wassen (van kleding en lijf) niet vanzelfsprekend was in een tijd van schaarste in een groot, armlastig gezin dat zich staande probeerde te houden in de oorlog.

Op de foto ziet $u$ het trouwboekje van de familie Zwakhalen, mijn grootouders. Dit was geen gemiddeld gezin. De familie Zwakhalen kwam veelvuldig in aanraking met de zorg thuis, met name voor geboortezorg maar liefst achttien keer. In dit gezin werden achttien kinderen geboren: het eerste kind in 1940, het laatste ruim twintig jaar later. Zoals u ziet, pasten ze niet allemaal in het boekje, waardoor niet iedereen is opgetekend. Mijn tante vertelde wel eens dat zij, als oma het gezin bij elkaar riep, vooral dacht: "O nee, niet alweer!" Als oudste meisje zag zij de bui immers al hangen.

In de jaren zestig verhuisde het gezin Zwakhalen naar de Ravelijn. In de Ravelijn werden veel gezinnen gehuisvest uit onder meer het Stokstraatkwartier (http://www.deravelijn.nl). Tegenwoordig is dit een van de meest luxueuze buurten van Maastricht, maar destijds werd deze gekenmerkt door verloedering en vernielingen. De Ravelijn was een 
sociaal-maatschappelijk experiment, dat je zou kunnen zien als een van de eerste integrale zorgprojecten. Het betrof een zogenaamde woonschool. De "beste sociaal zwakkere" gezinnen met bij voorkeur veel kinderen werden gehuisvest in een van de 104 woningen in de Ravelijn, in de nabije omgeving van een wijkcentrum waar alle zorg- en welzijnsondersteuning voorhanden was. Hier kregen de bewoners les in praktische vaardigheden, zoals huishouden en sociale vaardigheden. Het doel was heropvoeding door intensieve sociale en geestelijke zorg (Timmer, 2002; Bal, 2007). Ten grondslag aan het experiment van de woonschool in Maastricht lag het proefschrift van sociaal geograaf Harry Litjens (Litjens, 1953). Uiteraard was niemand in het gezin Zwakhalen zich bewust van het feit dat zij gescreend waren en onderdeel uitmaakten van een sociaal experiment. De Ravelijn is kenmerkend voor hoe de verpleging thuis in de loop van de jaren vijftig veranderde. Waar de zorg thuis voorheen gekenmerkt werd door haar ziektespecifieke karakter, was er in de jaren vijftig en zestig voor het eerst sprake van integrale zorg, waarbij een meer holistische visie leidend was (Duivesteijn-Ockeloen, 2016).

Mocht $u$ het willen weten: het woonschoolexperiment mislukte volledig. In plaats van integratie in de samenleving zorgde de woonschool juist voor segregatie, omdat de stigmatisering van wonen in de Ravelijn enorm was. Er werd geenszins gekeken naar de veerkracht van de bewoners, hun capaciteit en vermogen of de context. Van positieve gezondheid had nog niemand gehoord en de focus lag enkel op disfunctioneren. In de jaren tachtig werd het experiment beëindigd.

$\mathrm{Na}$ de oorlog was er sprake van toenemende welvaart en mobiliteit. De verpleegstersbromfietsen deden hun intrede: de solex als symbool van de zoevende zusters (www.nfi.nl).

In de jaren zeventig en tachtig ontstonden grote gezondheidscentra in de wijk. Uit de hoge ledenaantallen van de kruisverenigingen is op te maken dat de zorg in de wijk haar bestaansrecht had verworven. Maar liefst $80 \%$ van de gezinnen was lid van een kruisvereniging.

Met de invoering van de AWBZ, waardoor het kruiswerk werd gefinancierd, kreeg de overheid in toenemende mate invloed op de zorg thuis. Kruisverenigingen fuseerden en zo ontstonden logge bureaucratische organisaties die taakdifferentiatie stimuleerden. De verpleegkundigen in de wijk verloren hun zelfstandigheid (www.nfi.nl, Vilans, 2018).

Met de hervorming van de langdurige zorg in 2015 is er gelukkig veel veranderd voor de verpleging in de wijk. Om die veelal complexe zorg in de thuissituatie te kunnen garanderen werken verzorgenden en verpleegkundigen, zowel generalistisch als specialistisch en met uiteenlopende functies en niveaus, samen met andere zorgverleners (Vilans, 2018). De wijkverpleegkundige verricht naast toewijsbare zorgtaken ook coördinerende en signalerende taken. Zo is de wijkverpleegkundige sinds de hervorming verantwoordelijk voor de 
indicatiestelling en advisering over de zorgtoewijzing (Vilans). Deze taakuitbreiding vormde een sterke impuls voor de professionalisering. De verpleegkundigen en verzorgenden van nu richten zich in de thuissituatie op datgene wat voor cliënten van waarde is en op wat zij nog wél kunnen: hun vermogen en veerkracht (Huber et al., 2011). Daarmee doen zij dagelijks recht aan datgene wat door Virginia Henderson als verplegen werd gedefinieerd. Haar definitie van verplegen luidde: "Het individu, ziek of gezond bij te staan bij het verrichten van die activiteiten die bijdragen tot gezondheid of herstel (...), en die dit individu zonder hulp zou verrichten als hij de daartoe nodige kracht, wilskracht of kennis bezat. De verpleegkundige moet dit op zo'n wijze doen, dat de geholpene zo snel mogelijk weer onafhankelijk wordt." (Henderson, 1966).

In tegenstelling tot wat veel mensen denken, woont op dit moment slechts een klein gedeelte (ongeveer $5 \%$ ) van de ouderen in een verpleeghuis. In 1995 was dit nog ruim 17\%. Het aantal mensen dat gebruikmaakt van zorg thuis groeit dus gestaag. Veel mensen worden thuis oud, wat mogelijk is door de beschikbaarheid van de juiste zorgverlening. In die zin vormt de zorg thuis een belangrijk tegenwicht voor opname in een verpleeghuis (https://www.waardigheidentrots.nl).

Het merendeel, maar liefst $75 \%$, van de thuiswonende cliënten die thuis zorg ontvangen, is ouder dan 65 jaar. De e leeftijd waarop cliënten een beroep doen op zorg thuis is 75 . Met de stijging van de vraag is ook de complexiteit van de zorg toegenomen (Nederlandse Zorgautoriteit, 2018). De ouderen die thuis wonen hebben veelal te maken met meerdere aandoeningen, ook wel comorbiditeit genoemd, en komen daardoor in aanraking met veel verschillende zorgverleners.

Recent is in Maastricht in kaart gebracht welke ondersteuning vanuit de gemeente er door een aantal gezinnen werd gebruikt. Elk vakje is een gezin. De vakjes linksboven zijn de gezinnen die de meeste geïndiceerde ondersteuning ontvangen in het sociale domein. Daarbij kunt u denken aan huishoudelijke hulp, aangepast vervoer of maaltijdvoorziening. $\mathrm{Er}$ is duidelijk sprake van stapeling van de zorg, waarbij soms meer dan zeventien verschillende zorgverleners met hetzelfde gezin werken (Arrangementenmonitor Maastricht, 2018). Dat illustreert een complex, moeilijk te beheersen systeem dat nog sterk aanbod- en taakgericht is. Stelt $u$ zich eens voor dat dit het netwerk van mevrouw De Jong symboliseert en dat $u$ als casemanager dementie aan de slag moet binnen dit netwerk. Of dat u mevrouw De Jong zelf bent en te maken heeft met zeventien verschillende hulpverleners vanuit de gemeente...

Hoe kan wetenschappelijk onderzoek de zorg verbeteren?

Zonder wetenschap weten we niet of we doen wat het beste is. Zonder wetenschap zal de zorg die we verlenen niet excelleren en zullen we nooit verder komen dan gemiddelde zorg. En dat mag de zorg voor ouderen nou net niet zijn: gemiddeld. Gemiddeld impliceert namelijk dat het systeem, en niet de zorgvrager, leidend is (Ross, 2016). Ouderen die afhankelijk zijn van zorg verdienen beter. Onderzoekers proberen 
eigenlijk alleen maar de wereld om zich heen op een systematische en meetbare manier te beschrijven of te begrijpen. Naar die waarheid zoeken we. Aan onderzoek ligt ten allen tijde twijfel ten grondslag, die gebaseerd is op vragen uit de praktijk. Twijfel resulteert in een onderzoeksvraag. Dat wil ik graag illustreren aan de hand van een voorbeeld.

In 2003 zijn we begonnen met onderzoek naar pijn bij mensen met dementie. De vraag uit de praktijk was: ervaren mensen met dementie pijn op een soortgelijke wijze en kunnen we die pijn meten? Is het bijvoorbeeld mogelijk om zoiets als een pijnthermometer te ontwikkelen? Ouderen met dementie kunnen door hun cognitieve en verbale beperkingen vaak geen pijn aangeven. Verpleegkundigen moeten dan op basis van hun gevoel/ intuïtie, in combinatie met informatie uit het dossier of van familie, inschatten of ze pijn hebben. En zoals u weet zijn intuïtie en traditie mooie zaken, maar niet wenselijk in de wetenschap. Logischerwijs lukt dat inschatten van de pijn voor en door een ander vaak niet goed. Pijn is immers zeer subjectief. Tijdens mijn toenmalige promotietraject heb ik onderzocht welke bestaande pijnschaal geschikt zou zijn om pijn te meten bij ouderen met dementie. Na vier jaar zijn we erin geslaagd een schaal te ontwikkelen om pijn te meten bij deze doelgroep. Dankzij dit onderzoek hebben we de vaststelling van pijn kunnen verbeteren en weten we dat bijna de helft van de ouderen met dementie dagelijks pijn ervaart. De resultaten van de pijnstudie zijn gebruikt als input voor de totstandkoming van de richtlijn pijn bij kwetsbare ouderen van Verenso (2011). We kunnen dus stellen dat de resultaten van dit onderzoek eraan hebben bijgedragen dat pijn bij ouderen niet langer onopgemerkt blijft.

Hoe meer je weet, hoe duidelijker het ook wordt wat je nog niet weet. Telkens blijkt dat het meten, oftewel het scoren, van de pijn met behulp van de ontwikkelde instrumenten niet zo lastig is en ook niet heel tijdrovend. We zien echter dat hoge pijnscores niet resulteren in pijnreducerende interventies, zoals het toedienen van medicatie of een niet-farmacologische interventie zoals massage of afleiding door middel van muziek. Gegevens over het voorkomen van pijn worden niet optimaal benut om de zorg daadwerkelijk te verbeteren. Er is dus nog werk aan de winkel en ook in internationaal verband zullen we blijven werken aan de verbetering van zorg in geval van pijn bij dementie.

Hoe kan onderzoek naar de zorg voor ouderen thuis vorm krijgen? Het antwoord op die vraag is: op vele manieren. Maar ik zal er een manier uitlichten die voor ons van toepassing is. $U$ bent vandaag te gast in Maastricht, volgens velen de oudste stad van Nederland. Een stad vol historie, ook op het terrein van de verplegingswetenschap. Wat sommigen van u wellicht niet weten, is dat Maastricht de bakermat van de verplegingswetenschap kan worden genoemd. In 1980 ging in Maastricht de opleiding VW van start. Bij de toenmalige capaciteitsgroep Verplegingswetenschappen van de Rijksuniversiteit Limburg in Maastricht promoveerde vervolgens in 1984 een verpleegkundige genaamd Anneke 
van den Bergh-Braam. Voor zover ik weet is zij de eerste gepromoveerde verpleegkundige in Nederland. Twee jaar later mocht Anneke de eerste leerstoel VW bekleden, die was ingesteld door de UM. Daarmee werd Maastricht de universiteitsstad van waaruit het vakgebied zich verder ontplooide.

Voor Prof. Anneke van den Bergh-Braam was duidelijk dat een wetenschappelijk fundament noodzakelijk is om het verpleegkundige beroep verder te professionaliseren. Ik heb met veel plezier haar rede teruggelezen en wat opviel was haar pleidooi voor patiëntgerichte zorg. Ik citeer uit de oratie van Prof. Dr. Anneke van den Bergh-Braam uit 1986 (meer dan dertig jaar geleden): "Er wordt gekeken op allerlei formulieren, maar niet naar de patiënt." (Bergh-Braam van den, 1986). En hoewel verplegen, net als allerlei andere beroepen, context- en tijdgebonden is, lijkt deze uitspraak er een van alle tijden. De opvatting van Prof. Dr. Anneke van den Bergh-Braam was dat samenwerking noodzakelijk is om de patiëntenzorg te optimaliseren - samenwerking tussen organisaties in de eerste en de tweede lijn, maar ook tussen onderzoek, onderwijs en praktijk.

Dat gedachtegoed koesteren we ook vandaag de dag. Binnen Nederland is de laatste jaren immers hard aan de weg getimmerd om de academisering van de ouderenzorg verder vorm te geven. Momenteel bestaan er in Nederland zes Academische Netwerken Ouderenzorg. Elk van deze netwerken zorgt, door een nauwe samenwerking tussen wetenschappers, professionals en opleiders, voor effectieve kennisontwikkeling en -verspreiding. In Limburg bundelen we sinds 1998 onze krachten in de Academische Werkplaats Ouderenzorg Zuid-Limburg, kortweg AWO-ZL genoemd. De AWO-ZL, die vandaag haar twintigjarig jubileum viert, is een duurzaam en structureel samenwerkingsverband tussen de universiteit, het MBO (het Gilde), Zuyd Hogeschool Verpleegkunde en zeven grote zorgorganisaties. De huidige zorgvraag vraagt om interdisciplinaire samenwerking, die dan ook kenmerkend is voor de AWO, met haar interdisciplinaire leerstoelen (Verbeek et al., 2013). Onderzoekers op de werkplek en de praktijk op de universiteit: zo wordt een brug geslagen. Een trias academica in optima forma. Ik ben ervan overtuigd dat we met zijn allen binnen de AWO-ZL een verdere kwaliteitsimpuls kunnen geven aan de zorg voor ouderen thuis. Binnen mijn leeropdracht mag ik daar een substantiële bijdrage aan leveren.

Wat ga ik in de toekomst doen?

Ik zal u enkele paden tonen die ik de komende jaren binnen mijn leeropdracht ga bewandelen om de kwaliteit van de zorg voor ouderen thuis te verbeteren. Deze paden sluiten perfect aan bij de onlangs gelanceerde kennisagenda voor de wijkverpleging (V\&VN, 2018). Het zal u niet verbazen dat het daarbij draait om zowel onderzoek en onderwijs als praktijk. Omwille van de tijd, mijn grootste vijand in mijn leven, kan ik slechts een aantal onderzoeken noemen die gericht zijn op het primaire zorgproces enerzijds en de organisatie van de zorg voor ouderen thuis anderzijds. 


\section{Onderzoek}

Waarschijnlijk gaat u ervan uit dat, wanneer u zorg ontvangt, dit de juiste zorg of aanpak is voor uw klacht. Dat lijkt vanzelfsprekend, maar dat is het absoluut niet. We weten immers dat slechts een minderheid van de behandelingen en handelingen wetenschappelijk onderbouwd is. $\mathrm{Er}$ is dus een reële kans dat $u$ een behandeling ontvangt die niet de beste is, niet conform de richtlijn of zelfs schadelijk of overbodig (McGlynn et al. 2003).

Als het gaat om basiszorg, de meest voorkomende zorg in de verpleegkunde, zoals de zorg bij het wassen en aankleden van mevrouw De Jong, is bewezen effectieve zorg zeer schaars (Zwakhalen et al., 2018). Verreweg de meeste handelingen die verpleegkundigen en verzorgenden uitvoeren, zijn gebaseerd op praktijkervaring, niet op wetenschappelijke kennis. De zorg voor mevrouw De Jong lijkt misschien eenvoudige zorg, maar het tegendeel is waar. Zelfs de meest enkelvoudige handeling wordt vaak verricht binnen een uitermate complexe context en heeft vaak een doel dat vele malen groter is dan de handeling zelf. Denk bijvoorbeeld aan deze handeling: een cliënt met een hoog valrisico als gevolg van ondervoeding na een ziekenhuisopname ondersteunen bij het lopen in huis. Juist die basiszorg, die meest geleverde zorg, willen we verder onderbouwen met bewezen effectieve aanpakken (Zwakhalen et al., 2018).

Samen met de BASIC CARE REVISITED-groep voeren we gerandomiseerd gecontroleerd onderzoek uit naar interventies die gericht zijn op de ondersteuning van basiszorgactiviteiten. De onderzoeken van Annick van Manen naar de verbetering van de communicatie bij ouderen met dementie en het onderzoek naar wassen zonder water van Fabian Groven zijn daar mooie voorbeelden van. Bij dat laatste onderzoek wordt gekeken naar de waarde van wassen en de meerwaarde van WZW (een alternatieve wasmethode met verzorgende doekjes) voor cliënt, zorgverlener en mantelzorger als het gaat om bijvoorbeeld het ervaren comfort. Ook de onderzoeken onder leiding van Dr. Silke Metzelthin, wellicht beter bekend onder de naam Blijf Actief Thuis, en mooi voorbeeld van de verbetering van de zelfredzaamheid op het terrein van basiszorgactiviteiten zoals mobiliteit.

De resultaten van deze onderzoeken zetten we graag kracht bij door te blijven werken aan kwaliteitsstandaarden op het terrein van de ADL-zorg. Een dergelijke standaard geeft zorginhoudelijke aanbevelingen over de beste zorg bij een zorgvraag rondom ADL. Svenja Cremer is onlangs gestart met de ontwikkeling van deze ADL-kwaliteitsstandaard, onder leiding van onder meer Dr. Michel Bleijlevens.

Eén groep thuiswonende ouderen heeft binnen ons onderzoek een speciale plek: ouderen met dementie. Palliatieve zorg thuis in plaats van in een zorginstelling is voor ouderen een reële optie geworden. Via het onderzoek binnen het project DEDICATED proberen we verpleegkundigen te ondersteunen bij de zorg voor mensen met dementie. Onder leiding van onder meer Dr. Judith Meijers geeft Sascha Bolt hier verder invulling 
aan. Over een aantal jaren zal dit onderzoek resulteren in een toolkit voor betere toerusting van verpleegkundigen en verzorgenden bij de uitvoering van de zorg voor mensen in een palliatieve fase. Deze toolkit kan hen helpen om pijn te detecteren en de communicatie in een laatste levensfase op gang te brengen.

Mijn stellingname is dat de zorg voor ouderen thuis zeer divers en allesbehalve gemiddeld is. Maar hoe is het eigenlijk gesteld met deze zorg voor ouderen thuis? In een Europees onderzoek genaamd RightTimePlaceCare hebben we de zorg voor ouderen met dementie in kaart gebracht. Het is duidelijk geworden dat de zorg voor thuiswonende ouderen met dementie in Nederland bovengemiddeld is. Ouderen ervaren gemiddeld minder zorgproblemen, zoals pijn en ondervoeding, en gebruiken minder psychofarmaca dan vergelijkbare ouderen in andere EU-landen (Beerens et al., 2014). Maar zeggen deze gemiddelde cijfers ook echt iets over de kwaliteit? En kunnen we dit soort cijfers gebruiken bij processen voor de verbetering van de kwaliteit? Zorg is immers méér dan de afwezigheid van zorgproblemen en kan niet eenvoudigweg tot een gemiddelde worden herleid.

Denkt u nog eens aan mevrouw De Jong. Zij was niet ondervoed of gevallen of iets dergelijks. Wat zou goede kwaliteit in haar geval inhouden? Voor cliënten is kwaliteit een dynamisch proces dat gestalte krijgt binnen de relatie die wordt aangegaan. Binnen Limburg Meet werkt Roy Haex samen met onder meer Dr. Theresa Thoma aan de ontwikkeling en het testen van een methodiek om deze kwaliteit vanuit het perspectief van de cliënt in kaart te brengen.

Om de kwaliteit echt te verbeteren is meer nodig dan het inventariseren van zorgproblemen met behulp van zogenaamde afvinklijstjes. Leidend wordt de op persoonsniveau gerichte informatie die de kwaliteit en uitkomsten van de verleende zorg inzichtelijk maakt (REF). Daarvoor is het noodzakelijk dat medewerkers samen werken aan een cultuur waarin leren en verbeteren in het DNA zit. Een cultuur waarin kwaliteitsgevevens aanleiding geven voor kritische reflectie ter verbetering van de zorg. Een cultuur waarin ieders competenties en expertise op waarde geschat en ingezet worden en waarin van elkaar leren tot norm wordt verheven. Een traject waarbij wordt ingezet op levenslang leren op de werkplek. In het onlangs gehonoreerde project "Leren en verbeteren" gaan we daar binnen de AWO aan werken. Een gerelateerd thema dat daarbinnen verder onderzoek verdient, is verpleegkundig leiderschap, dat het middelpunt vormt van het onderzoek van Ruth Vogel.

Ik wil u vragen om allen even te gaan staan voor een aantal korte vragen:

- Een Nederlandse man is gemiddeld 1,83 meter lang en een Nederlandse vrouw gemiddeld 1,68 meter. $U$ mag gaan zitten als $u$ als vrouw geen $1,68 \mathrm{~m}$ bent of als man geen $1,83 \mathrm{~m}$. Overigens is het land van herkomst sterk bepalend voor iemands lengte, die daarmee een maatstaf voor welzijn/gezondheid vormt. 
- Een man weegt gemiddeld $84 \mathrm{~kg}$ en een vrouw $70 \mathrm{~kg}$. Als $\mathrm{u}$ als man geen $84 \mathrm{~kg}$ weegt of als vrouw geen $70 \mathrm{~kg}$, mag u eveneens gaan zitten.

- Een man heeft gemiddeld schoenmaat 43, een vrouw 39. Mocht u nog staan en niet aan deze maatstaven voldoen, dan mag u gaan zitten.

Aan de hand van deze parameters heb ik geïllustreerd dat er, hoewel veel onderzoek met gemiddelden werkt, maar weinig gemiddelde mensen bestaan. De zorg voor ouderen thuis kent eveneens geen gemiddelde oudere. Onderzoek op het gebied van zorg voor ouderen vraagt dan ook om meer en wellicht ook nieuwe onderzoeksmethoden: methoden die recht doen aan de diverse werkelijkheid en niet aan gemiddelden. Geblindeerde gerandomiseerde praktijkonderzoeken, waarbij mensen door toeval worden toegewezen aan een groep die een bepaalde interventie ontvangt, behoren niet altijd tot de mogelijkheden. Ik heb de diversiteit van deze ouderen geïllustreerd en u kunt zich misschien voorstellen hoe lastig het is om alleen al twee vergelijkbare groepen te vormen. Gerandomiseerd gecontroleerd onderzoek is wat mij betreft van grote waarde en kan op veel gezag rekenen, maar voor veel vraagstukken is er meer nodig dan deze "heilige graal". Dat geldt ook voor uitkomstmaten. We richten ons op zeer rigide en moeilijk te beïnvloeden maten, die veelal op functionaliteit gericht en vaak niet verpleegkundig van aard zijn. In een context van ouder worden is verbetering van het functioneren vaak niet haalbaar en gaat het misschien om veel subtielere verbeteringen.

De resultaten van de verschillende onderzoeken zullen ook worden gebruikt voor theorievorming. Het lijkt erop dat verpleegkundigen steeds vaker het belang van verpleegkundige theorie uit het oog verliezen. Mogelijk biedt de theorie niet voldoende handvatten. Zoals reeds genoemd is verplegen tijd- en contextgebonden (Lambregts et al., 2015), en dat geldt ook voor de theoretische grondslag ervan. Gezien de verandering die de verpleegkunde heeft doorgemaakt, gekenmerkt door een praktijkveld dat steeds meer in het sociale domein opereert, is het wellicht tijd om de theorie zo aan te passen dat deze richting geeft aan onderzoeksvragen en toepassingen in de dagelijkse praktijk. Toekomstig onderzoek zal hier verdere input voor leveren.

Voor de onderzoekvragen waarop ik me richt, is discipline overstijgende kennis onontbeerlijk. Ik heb dan ook een sterke voorkeur voor interdisciplinaire samenwerking. De komende jaren zal ik met vele collega's met zeer diverse achtergronden (onder meer arbeids- en organisatiepsychologie, marketing, onderwijskunde) verder bouwen aan kennis binnen de genoemde en toekomstige projecten.

\section{Onderwijs}

Opgedane kennis heeft alleen waarde als deze wordt uitgedragen via relevante onderwijsactiviteiten. We zullen professionals in opleiding moeten motiveren om voor het vak te kiezen en erbinnen te blijven 
werken. Er bestaat immers een schaarste die we ons allen moeten aantrekken.

In mijn rol als hoogleraar Verplegingswetenschap zal ik een substantiële bijdrage leveren aan de onderwijsprogramma's van de Universiteit Maastricht en Zuyd Hogeschool. Binnen FHML worden een bacheloropleiding Gezondheidswetenschappen (GW) en diverse masteropleidingen, waaronder HPIM, aangeboden. Beide zijn voor de leerstoel bijzonder relevant. Wat betreft onderwijsinbedding bij Zuyd Hogeschool zullen de onderwijsactiviteiten voornamelijk gericht zijn op de hbo-opleiding Verpleegkunde. Concreet betekent dit dat er vanuit de leerstoel onderwijs zal worden ontwikkeld en verzorgd op het terrein van de vastgestelde thematiek, met een interprofessionele focus. Daarbij gaat het onder andere om de inbreng van wetenschappelijke kennis in het curriculum en de toepassing van die kennis via evidence-based handelen. Binnen Zuyd Hogeschool wordt momenteel, onder de vlag van de AWO, een duaal traject vormgegeven. Binnen dit traject zullen studenten kort na de start worden opgeleid tot generalisten in de ouderenzorg. Zij leren op de werkplek van en met elkaar.

Vanaf 2016 is in Nederland het tweejarige leiderschapsprogramma "Leadership Mentoring in Nursing Research" (LMNR) ontwikkeld voor veelbelovende gepromoveerde verplegingswetenschappers. Hoogleraar Prof. Dr. Marieke Schuurmans stond, samen met haar collega's Prof. Dr. Jan Hamers en Prof. Dr. Theo van Achterberg, aan de wieg van dit prachtige programma, waaraan ik graag mijn bijdrage lever.

Binnen de European Academy of Nursing Science (https://european-academy-of-nursing-science.com) begeleiden we in Europees verband verpleegkundigen tijdens hun promotietraject. Ook binnen dat programma zal ik mij blijven inzetten.

\section{Praktijk}

Dr. Theresa Thoma heeft enige jaren geleden (2015) binnen de AWO-ZL geïnventariseerd welke innovaties er binnen de organisaties gebruikt werden. Haar conclusie luidde: de innovatiekracht in de organisaties voor ouderenzorg is enorm. Er gebeurt te veel om op te noemen. Met de bestuurders, linking pins en alle zorgverleners uit de praktijk zullen we toekomstige vraagstukken oppakken en kennis laten terugvloeien.

Daarvoor is het noodzakelijk dat we elkaars kracht kennen en benutten.

$\mathrm{Na} \mathrm{u}$ te hebben meegenomen in de zorg voor ouderen thuis, waarbij de verbinding tussen onderzoek, onderwijs en praktijk in dat zorgsegment voorop stond, kom ik langzaam tot een afronding. Voor mezelf en mijn eigen onderzoeksgroep zou ik zeggen: we zijn pas net begonnen. Er zijn nog veel praktijkvragen in de zorg voor ouderen thuis waarvoor meer kennis nodig is om te zorgen dat verpleegkundigen bij alle cliënten, hoe divers die ook mogen zijn, onderbouwd kunnen handelen in hun dagelijks zorgverlening. 
En welke boodschap neemt u mee naar huis?

Als $u$ onderzoeker bent in de zorg voor ouderen thuis, dan bent u mijn 'partner in crime'. Samen kunnen we de kwaliteit van zorg verbeteren en het verpleegkundig beroep verder professionaliseren.

Als $u$ zelf op leeftijd bent en eventueel ondersteuning nodig heeft, dan hoop ik dat u meer zicht heeft gekregen op de zorg voor ouderen thuis. $U$ bent als ervaringsdeskundige van groot belang en u stem zal in de toekomstige onderzoeksprojecten een stevige zijn.

Bent je student? Dan rest je een belangrijke taak. Verpleegkunde is het mooiste vak dat u kunt kiezen. Wetenschap bedrijven erin het aller... allermooiste.

En als $u$ docent of opleider bent, laten we ons dan gezamenlijk inzetten voor de volgende generaties verzorgenden, verpleegkundigen en verplegingswetenschappers. Want er zijn er heel, heel, heel veel nodig in de zorg voor ouderen.

Bent u financier dan is de boodschap tweeledig. Mijn waardering is enorm voor de impuls die er afgelopen decennia is gegeven aan de verplegingswetenschap. Mede door Tussen Weten en Doen (TWD), een ZonMw-programma, heeft de onderzoeksinfrastructuur voor wetenschappelijk onderzoek voor verpleging en verzorging een impuls gekregen.

Maar .... De laatste tijd ligt er veel nadruk op implementatie... Zeer veel nadruk. Investeren in theoretische onderbouwing mag niet ontbreken. Evenmin onderzoek naar kennis over wat werkt en wat niet werkt. Nog steeds is te veel verpleegkundig handelen niet onderbouwd.

Wetenschappelijk onderzoek naar nieuwe kennis en replicatiestudies zijn echt onontbeerlijk.

Bent u decaan of vice-decaan van deze faculteit. Allereerst is mijn waardering groot voor het verwezenlijken van deze leerstoel en daarmee de boodschap dat Maastricht een leerstoel Verplegingswetenschap verdient. Verplegingswetenschappelijk onderzoek is inmiddels sterk verankerd in Maastricht. Het aantal promotietrajecten dat wij in Maastricht kunnen aangaan met verpleegkundige is echter zeer gering. Master opgeleide verpleegkundigen zijn schaars. Ik roep u dan ook graag op om samen te kijken hoe we in de toekomst verplegingswetenshap in Maastricht verder leven in kunnen blazen.

Maar welke rol u ook heeft, we hebben elkaar heel hard nodig voor ons onderzoek, onderwijs en praktijk.

\section{DANKWOORD}


Het is voor mij een enorme eer vandaag deze leerstoel te mogen aanvaarden. Ik dank hiervoor het college van bestuur van de Universiteit Maastricht en Zuyd Hogeschool. In het bijzonder wil ik de decaan, Prof. Dr. Albert Scherpbier en de vice decaan Prof. Dr. Nanne de Vries, van onze faculteit FHML, danken voor hun visie en inzet.

In de afgelopen jaren hebben velen mij de kans gegeven om te leren en me te ontwikkelen. Mijn eerste stappen in de wetenschap zette ik in Maastricht. Onder toeziend oog van Prof. Dr. Huda Huijer (destijds hoogleraar VW) en Prof. Dr. Martijn Berger startte ik een promotietraject. Vanaf dat moment omarmde ik de wetenschap. Veel dank.

Professor Dr. Ruud Kempen, samen met Professor Dr. Jan Hamers run je het onderzoeksprogramma Ageing and Long-Term Care. Een prachtig onderzoeksprogramma met een duidelijke focus dat de afgelopen jaren floreerde. Veel dank voor alle support.

Professor Dr. Jan Hamers, voorzitter van de Academische Werkplaats Ouderenzorg Zuid-Limburg en mede- programmaleider: dank voor je vertrouwen en de mogelijkheden die je me bood om een eigen koers uit te zetten al die jaren. Wat heb ik veel van je geleerd! .......Vanaf het moment dat ik mijn ambitie om een leerstoel te bekleden kenbaar heb gemaakt, heb jij je daar sterk voor gemaakt. Dankjewel! Zonder je steun was dit niet mogelijk geweest. En dank je vooral voor je duidelijke visie en de inspirerende manier waarop je verpleegkundig leiderschap vormgeeft. Uit jouw schaduw treden zal niet meevallen.....VW in Maastricht is namelijk analoog geworden aan Jan Hamers.

Veel dank ben ik verschuldigd aan het management team van de Academische Werkplaats Ouderenzorg Zuid-Limburg en het management team van Health Services Research. De vakgroep die onder leiding van Professor Dirk Dr. Ruwaard groeit en groeit. Mijn dank is groot aan alle collega's van HSR.

Ik dank het bestuur, de directeur, lectoren en de docenten van Zuyd Hogeschool. Ik ben oh zo trost dat jullie de totstandkoming van de leerstoel ondersteunen. Ik kijk uit naar de samenwerking in de toekomst. Het is zeker niet mijn ambitie om van alle toekomstig verpleegkundigen onderzoekers te maken maar wel om hun verpleegkundig handelen te doorspekken met evidentie, wetenschappelijke kennis die hun klinisch redeneren kan aanscherpen.

Allen die werkzaam zijn binnen de AWO-ZL. Woorden kunnen niet uitdrukken hoe groot jullie rol is. Samen zetten we ons in voor het verbeteren van de kwaliteit van leven en zorg voor ouderen. Er zijn weinig voorbeelden waar praktijk, onderzoek en onderwijs zo hand in hand gaan. Ik ben er trost op, er onderdeel van te mogen zijn. 
Bij al het mooie onderzoek waarover ik vandaag heb verteld, spelen studenten, promovendi en postdocs een onmisbare rol. Samen zetten we de koers uit. Zonder jullie was er geen onderzoek. Ik ben oh zo trots op jullie!

Mijn werk zou onmogelijk zijn zonder de ondersteuning van de diverse secretariaten binnen onze vakgroep, allen een dikke Merci. In het bijzonder een woord van dank aan Joanna Houtermans voor alle ondersteuning die mijn dagelijks werk een pak gemakkelijker maakt.

Velen met wie ik samenwerk ben ik dankbaar. Iedereen die bijdraagt aan het wetenschappelijk onderzoek in de verpleging; collega hoogleraren, lectoren, practoren, de medewerkers van de beroepsvereniging $\mathrm{V} \& \mathrm{VN}$, inspectie etc.

Een bijzonder woord van appreciatie gaat uit naar mijn collega hoogleraren verbonden in het onlangs opgerichte wetenschappelijk college verplegingswetenschap, het WCV. We zijn met 13 hoogleraren en dat we elkaar zo gemakkelijk weten te vinden is een opbrengst van ieders inspanning. Mijn waardering voor jullie is groot en ik kijk vooral uit naar de verdere samenwerking.

Hooggeleerde en vooral zeer gewaardeerde Prof. Dr Gaby Odekerken. Dank je voor je mentorschap. Dank dat ik gebruik mag maken van je kennis, expertise en ervaring. Ik waardeer je oprechtheid en openheid. Veel dank Gaby!

Colleagues of the European Academy of Nursing Science, headed by Prof. Dr. Gabriele Meyer. Many thanks for offering young scientist an inspiring environment. It made my who I am...

Daarnaast heb ik ook met veel andere groepen mogen samenwerken. Ik kan hen niet allemaal noemen. Een bijzondere plek in mijn wetenschappelijk bestaan heeft de Basic Care Revisited groep. Het is onze gezamenlijke ambitie om essentiële zorg op de kaart te zetten en wetenschappelijk te onderbouwing. Ik apprecieer onze gezamenlijke inzet.

Een woord van dank ook aan het Universiteitsfonds Limburg, het SWOL voor de financiële ondersteuning van deze mooie dag en meer specifiek het symposium deze ochtend.

Als wetenschapper heb je te maken met het rare fenomeen dat je geen beroep hebt maar je beroep bent. Wetenschap bedrijven doe je niet enkel tussen 9.00 en 17.00 uur. En juist daarom is het goed te beseffen dat er zo veel meer is. Vrienden en familie, dank voor alle mooie momenten. Dankzij jullie is er meer dan wetenschap. 
En dan het thuisfront, van het allergrootste belang. Wim Toen we elkaar ontmoette kreeg ik een bonus: Lyna en Ilke. Een VPT zouden ze in termen van zorg thuis zeggen. ...In de stad, Geel, die wereldwijd geroemd is voor haar model voor de gezinsverpleging mag ik met je wonen. Je bent mijn steun en toeverlaat en met jouw kan ik zo veel meer delen dan wetenschappelijke kennis. Mijn werk, kan ik enkel en alleen naar behoren uitvoeren omdat jij zorgt voor alle stabiliteit in ons gezin.

De dagen gaan voorbij, veel te snel.... Wat ben je al groot lieve Stan. Dank voor je ontnuchterende vragen. Wat heb je vandaag ontdekt, vraag je met enige regelmaat. En als ik het antwoord dan schuldig moet blijven, zie ik je denken.... dat is dan een professor. Die gedachte alleen is voldoende om de macht van de wetenschap te relativeren. Als ik naar je kijk dan denk ik maar een ding: Hoe mooi kan het leven toch zijn. Blijf jezelf en wordt gelukkig, dat is de belangrijkste opdracht in het leven.

Pap, ik vind het fantastisch dat we zo veel mooie momenten samen kunnen delen. Samen naar Buenos Aires naar het wereld pijncongres. Ik erfde je introversie maar ook je positieve blik. Je leesdrift en hopelijk vooral je warme menselijke waarden. Jij bent bij uitstek een selfmade men. Op je $11^{\mathrm{e}}$ van school en werken. Leren laat staan studeren, is immers tijdsverspilling in een gezin met 18 kinderen. Daar gelden andere prioriteiten. Je bent voor mij het beste voorbeeld van hoe iemand zijn eigen weg baant. Studeren was in de familie geen vanzelfsprekendheid, geen rolmodellen. Maar jij hebt me vooral geleerd dat je uiteindelijk zelf verantwoordelijkheid bent voor je leven. Kijken naar waar iedereen naar kijkt en toch zien wat anderen misschien niet zien. Daar ligt de basis voor mijn wetenschappelijke blik. Bereiken wat misschien vooraf onmogelijk lijkt. Deze rede is daarom opgedragen aan mijn vader voor wie ik ontzettend veel bewondering heb.

Ik heb gezegd.

De projecten waarna wordt gerefereerd in de tekst zijn te vinden op de website van de AWO-ZL; https://www.academischewerkplaatsouderenzorg.nI 
Arrangementenmonitor Maastricht 2018, www.blauwezorg.nl/blauwezorg-in-de-wijk/

Bal, F. (2007). De mislukte heropvoeding van onmaatschappelijken. Het bij elkaar zetten van probleemgezinnen maakte hun leven juist moeilijker. Historisch Nieuwsblad 8.

Beerens, H.C., et al. (2014). Quality of life and quality of care for people with dementia receiving long term institutional care or professional home care: The European RightTimePlaceCare study. Journal of the American Medical Directors Association, 15, 54-61.

Bergh-Braam, A.H.M. van den Bergh-Braam. (1986).

Verplegingswetenschap in Nederlands perspectief. Leiden: Spruyt, Van Mantgem en De Does.

Boom van der, H., Philipsen, H. \& Stevens, F. (2004). Een schets van de professionalisering van de wijkverpleging in Nederland in de laatste vijftig jaar (1950-2004). Gewina, 27, 100119.

Dane, C. Geschiedenis van de ziekenverpleging ( $9^{\mathrm{e}}$ druk; Utrecht 1994)

Duivesteijn-Ockeloen, K. (2016). Op zoek naar de 'totale mens'. Taak, verantwoordelijkheid en identiteit van de verpleegkunde in Nederland 1955-1988. Proefschrift.

Henderson, V. (1966). The nature of nursing: A definition and its implications, practice, research, and education. Macmillan Company, New York.

https://www.waardigheidentrots.nl/wpcontent/uploads/2016/08/Verpleeghuiszorg-2025.pdf

Huber, M. (2011). How should we define health? BMJ. 343:d4163.

Hulst van, A.G. (1916). Reinheid, rust en regelmaat: Een beknopte uiteenzetting hoe moeders hare zuigelingen op de minst omslachtige wijze goed kunnen verzorgen. Algemeene Nederlandsche Vereeniging Het Groene Kruis.

Lambregts, J.A.M., Grotendorst A., van Merwijk A.C.S.J. Stuurgroep bacherlor nursing 2020. (2015). Een toekomst bestendig opleidingsprofiel 4.0 .

Litjens, H.P.M. (1953). Onmaatschappelijke gezinnen: Sociologisch 
onderzoek naar de onmaatschappelijkheid te Maastricht. Assen: Van Gorcum.

McGlynn, E.A., et al. (2003). The quality of health care delivered to adults in the United States. N Engl J Med, 348, 2635-2645.

Nederlandse Zorgautoriteit. Monitor zorg voor ouderen 2018.

Ross, T. (2017). The End of Average: How We Succeed in a World That Values Sameness.

Thoma-Lu" rken, T., et al. (2015). Innovaties in de ouderenzorg. Een inventarisatie van potentieel arbeidsbesparende en kwaliteitsverbeterende innovaties binnen de Limburgse ouderenzorg. Rapport in opdracht van de Provinciale Raad voor Volksgezondheid.

Timmer, P., 'Woonscholen in Nederland. (2002). De Ravelijn in Maastricht als laatste herinnering', Historisch geografisch tijdschrift 20.

Verbeek, H et al. (2013). Keys to Successfully Embedding Scientific Research in Nursing Homes: A Win-Win Perspective. Journal of the American Medical Directors Association, (14),12, 855 - 857.

Verenso. (2011). Multidisciplinaire Richtlijn Pijn, Herkenning en behandeling van pijn bij kwetsbare ouderen. Utrecht: Verenso.

Vilans. De wijkverpleegkundige door de tijd heen.

https://www.vilans.nl/vilans/media/documents/producten/verledentoekomst-wijkverpleegkundige.pdf

Vilans, 2018.

https://www.vilans.nl/vilans/media/documents/producten/uitdagingenen-knelpunten-van-de-wijkverpleging.pdf

Website Florence Nightingale Instituut. https://www.fni.nl/

Website de Ravelijn. http://www.deravelijn.nl

Website V\&VN. https://www.venvn.nl/wijkverpleging

Zwakhalen, S.M.G., et al. (2018). Basic nursing care: the most provided, the least evidence based. A discussion paper. J Clin Nurs, 27, $11-12$. 